Original Article - Clinical Science

\title{
Prevalence and risk profile of retinopathy in non-diabetic subjects: National Health and Nutrition Examination Survey 2005 to 2008
}

\author{
Zhuoting Zhu MD, ${ }^{1}$ Wei Wang MD PhD, ${ }^{1}$ J ane Scheetz $\mathrm{PhD}^{2}$ J ian Zhang $\mathrm{MSc}^{2}$ and \\ Mingguang He MD PhD ${ }^{1,2}$
}

1. State Key Laboratory of Ophthalmology, Zhongshan Ophthalmic Center, Sun Yat-sen University, Guangzhou, China.

2. Centre for Eye Research Australia; Ophthalmology, Department of Surgery, University of Melbourne, Melbourne, Australia.

Correspondence: Mingguang He, Zhongshan Ophthalmic Center, Guangzhou 510060, People's Republic of China; Centre of Eye Research Australia, University of Melbourne, East Melbourne 3002.

Email: mingguang.he@unimelb.edu.au

Short running title: Retinopathy in non-diabetic subjects

Received 8 March 2019; accepted 13 J uly 2019

This is the author manuscript accepted for publication and has undergone full peer review but has not been through the copyediting, typesetting, pagination and proofreading process, which may lead to differences between this version and the Version of Record. Please cite this article as doi: 10.1111/ceo.13595

This article is protected by copyright. All rights reserved. 
Funding sources / Financial disclosure: The present work was supported by Fundamental Research Funds of the State Key Laboratory in Ophthalmology. Prof. Mingguang He receives support from the University of Melbourne at Research Accelerator Program and the CERA Foundation. The Centre for Eye Research Australia receives Operational Infrastructure Support from the Victorian State Government. The sponsor or funding organization had no role in the design or conduct of this research. Conflict of interest: None

\section{ABSTRACT}

I mportance: Recent U.S. national population-based data on the prevalence retinopathy in non-diabetic participants is limited.

Background: To assess the prevalence and risk factors for retinopathy in a representative U.S. population without diabetes.

Design: Population-based, cross-sectional study.

Participants: A total of 4,354 non-diabetic participants 40 years and older with valid fundus photographs in the 2005 to 2008 National Health and Nutrition Examination Survey (NHANES).

Methods: Diabetes mellitus was defined as glycosylated hemoglobin $\geq 6.5 \%$, physician diagnosis of diabetes mellitus, or use of diabetic medication. Retinopathy level was based on the Modified Airlie House adaptation from the Early Treatment Diabetic Retinopathy Study (ETDRS) protocol. Risk profile was assessed from standardized interviews, clinical examinations and laboratory measurements.

Main Outcome Measures: Prevalence and risk profile of retinopathy in non-diabetic participants.

Results: The overall weighted prevalence of retinopathy was $6.7 \%(n=341)$. Among 
them, $98.2 \%$ ( $n=331$ ) had signs of minimal-to-mild non-proliferative retinopathy (ETDRS level 14-31) while only $1.8 \%(n=10)$ had moderate-to-severe non-proliferative retinopathy (ETDRS level 41-51). After adjusting for multiple covariates, retinopathy signs in non-diabetic participants were associated with male gender (odds ratio[OR], 1.54; 95\% Confidence Interval[Cl], 1.22 to 1.93 ), systolic blood pressure (OR per $10 \mathrm{mmHg}$ increase, 1.11; 95\% Cl, 1.03 to 1.19), HbAlc (OR per \% increase, 1.43; $95 \% \mathrm{Cl}, 1.01$ to 2.05 ), and history of stroke (OR, $2.39 ; 95 \% \mathrm{Cl}$, 1.14 to 5.04$)$.

Conclusions and relevance: Consistent with previous studies, signs of retinopathy are common in U.S. persons without diabetes. Risk factors for retinopathy signs include gender, blood pressure, HbAlc and history of stroke.

Keywords: retinopathy prevalence; non-diabetic subjects; risk profile. 


\section{I NTRODUCTI ON}

There is increasing evidence that lesions associated with retinopathy (e.g., microaneurysms, soft/hard exudates, and/or retinal hemorrhage) are frequently detected in persons without diabetes. According to previous studies, ${ }^{1-4}$ up to $15 \%$ of non-diabetic persons showed retinopathy. Despite the documented prevalence of retinopathy in the U.S. non-diabetic population, ${ }^{1,5-7}$ these studies estimated the prevalence of retinopathy from specific ethnicity or several communities conducted in the late 1990s. However, recent national population-based data on the prevalence retinopathy in non-diabetic participants remains scarce.

Unlike established risk profiles for diabetic retinopathy, risk factors for retinopathy signs among participants without diabetes have not been consistent across diverse populations. Several studies have reported associations between retinopathy and various cardiovascular risk factors, such as hypertension ${ }^{5,8,9}$ and obesity. ${ }^{9,10}$ While other studies have shown independent risk factors for retinopathy in non-diabetic participants including increased serum glucose, ${ }^{10-14}$ increased urinary albumin excretion ${ }^{11,12}$ and systemic markers of inflammation. ${ }^{15}$

Therefore, in this study, we investigated the prevalence and risk profile in a recent nationally representative cohort of U.S. residents.

\section{METHODS}

\subsection{Sample and Population}

National Health and Nutrition Examination Survey (NHANES) is a national representative survey including a comprehensive in-person interview and extensive examinations conducted every two years. The dataset obtained a representative 
sample of the civilian and non-institutionalized U.S. population through a stratified multistage probability design with intentionally oversampling of certain age and racial/ethnicities. ${ }^{161616}$ In the current analysis, we merged the dataset of the NHANES from 2005 to 2008. Written informed consent was obtained from all participants. This research adhered to the tenets of the Declaration of Helsinki, and ethics was approved by the National Center for Health Statistics research ethics review board.

\subsection{Assessment of Retinopathy}

Non-mydriatic retinal photography was performed using the Canon CR6-45NM Ophthalmic Digital Imaging System and a Canon EOS 10D digital camera (Canon USA Inc., One Canon Park, Melville, New York) for participants over 40 years of age. Fundus photographs were graded at the University of Wisconsin Ocular Epidemiologic Reading Center, Madison. Quality control of images capturing and grading has been described in detail elsewhere. ${ }^{17}$ Retinopathy severity was graded according to the Early Treatment Diabetic Retinopathy Study (ETDRS) grading standard: no retinopathy (level 10-13), minimal-to-mild non-proliferative retinopathy (level 14-31), moderate-to-severe retinopathy non-proliferative retinopathy (level 41-51), and proliferative retinopathy (level > 60). ${ }^{18}$ If retinal images were available for both eyes, we used the data from the eye with more severe disease status in our analysis.

\subsection{Risk Profile Assessment}

Risk profile assessment included demographic factors, health-related behaviors, and general health characteristics. Ethnicity was classified as Non-Hispanic White, Non-Hispanic Black, Mexican American, and other. Education level was classified as less than high school degree and equal to or more than high school diploma. Marital status was divided as unmarried and other, or married/with a partner. Poverty income 
ratio $(P I R)$ was categorized as below poverty $(<1.00)$ and above poverty $(\geq 1.00)$. Smoking status was defined as two groups: (1) never and (2) former/current smoker. Self-reported alcohol consumption was divided as lifetime abstainer/former drinker, current drinker with equal to or less than 3 drinks per week and those who consumed more than 3 drinks per week. The 2008 Physical Activity Guideline for Americans suggests at least 2.5 hours of moderate-intensity or 75 minutes of vigorous-intensity aerobic physical activity per week, or an equivalent combination of moderate- and vigorous intensity aerobic activity for substantial health benefits. ${ }^{19}$ We categorized participants into two groups based on whether the 2008 Physical Activity Guidelines were met or not.

Body mass index (BMI) was calculated as weight in kilograms divided by height in meters squared. A digital automatic blood pressure monitor was used to measure systolic blood pressure (SBP) and diastolic blood pressure (DBP) and the mean of three measurements was used for analysis. Hypertension was defined as an averaged $\mathrm{SBP} \geq 140 \mathrm{~mm} \mathrm{Hg}, \mathrm{DBP} \geq 90 \mathrm{~mm} \mathrm{Hg}$, physician diagnosis or use of antihypertensive medication.

Non-fasting blood samples and urine samples were collected and sent for analysis of glycosylated hemoglobin levels (HbAlc), glucose, creatinine and serum lipids [total cholesterol, and high-density lipoprotein (HDL)] to a central laboratory (White Sands Research Center, Alamogordo, NM). Diabetes mellitus was characterized as physician diagnosis or the use of insulin/diabetic tablets, or $\mathrm{HbAlc} \geq 6.5 \%$. Glycemia status was categorized as normoglycemia ( $\mathrm{HbAlc}<5.7 \%)$ and prediabetes $(5.7 \% \leq \mathrm{HbAlc} \leq$ $6.49 \%)$. Individuals were diagnosed as having hyperlipidemia with the total serum cholesterol $\geq 240 \mathrm{mg} / \mathrm{dL}$ or the use of a lipid-lowering agent. Individuals with high C-reactive protein (CRP) level was based on a CRP of $\geq 1 \mathrm{mg} / \mathrm{dL}$. Presence of chronic kidney disease (CKD) was defined as estimated glomerular filtration rate (eGFR) $<60$ 
$\mathrm{ml} / \mathrm{min} / 1.73 \mathrm{~m}^{2}$ or urine albumin-creatinine ratio $(A C R) \geq 30 \mathrm{mg} / \mathrm{g}$.

\subsection{Statistical Analysis}

Stata (version 14.0; StataCorp., College Station, TX) was used for all statistical analysis. All analysis took the complex, stratified design of NHANES into account. Sampling weights for the present study were the four-year mobile examination center (MEC) weights. Basic characteristics of the study population with any retinopathy are presented as using means and standard errors (SE) for approximately normally distributed continuous variables and medians and interquartile range (IQR) for skewed continuous variables, and numbers and weighted percentages for categorical variables. We used the design-adjusted t-test or Mann-Whitney test, and Rao-Scott Pearson $x^{2}$ for the comparison of continuous and categorical variables, respectively. Logistic regression models were used to estimate the odds ratios (OR) and $95 \%$ confidence intervals $(\mathrm{Cl})$ for associations between retinopathy and risk factors. Age and gender-adjusted logistic regression models were used to determine baseline characteristics significantly associated with the presence of any retinopathy. Covariates with $\mathrm{P}<0.1$ in logistic regression analysis considering age and gender were added to final multivariable models. The regression analysis in subgroups stratified by glycemia status and hypertension were repeated. All comparisons used a two-sided significance level of $5 \%$.

\section{RESULTS}

A total of 6,797 participants aged 40 years or older participated in the NHANES 2005-2008. Among these individuals, 2,443 participants were excluded because of missing information on diabetes mellitus status $(n=272)$, diagnosis of diabetes 
mellitus ( $n=1,424)$, missing or ungradable photographs in both eyes $(n=668)$, those with advanced retinopathy that might be a result of diabetes status misclassification ( $\mathrm{n}$ $=0$ ), and retinopathy due to other specific non-diabetic disease ( $n=79$, e.g. retinal vein occlusion). This left a final sample of 4,354 (72.2\%; 2163 [47.0\%] men; 2517 [79.6\%] white; mean [SE] age, 55.6 [0.4] years) participants for analysis. Compared with included participants, excluded participants were likely to be older, black ethnicity, less educated, unmarried, in lower income level, abstainer/former drinker and unhealthier. Demographic, health-relate behaviors and characteristics of excluded and included subjects are shown in Supplement Table 1.

Table 1 illustrates the characteristics of non-diabetic participants by overall and retinopathy status. The weighted prevalence of any retinopathy was $6.7 \%$ (95\% confidence interval $[\mathrm{Cl}], 5.9 \%$ to $7.6 \%, \mathrm{n}=341$ ). Among them, 331 (weighted prevalence: $98.2 \%$; $95 \% \mathrm{Cl}, 96.4 \%$ to $99.1 \%$ ) of these 341 participants had minimal-to-mild retinopathy, and only 10 (weighted prevalence: $1.8 \% ; 95 \% \mathrm{Cl}, 0.9 \%$ to 3.6\%) had moderate-to-severe retinopathy. Retinopathy signs were present in 5.9\% (95\% Cl, $5.0 \%$ to $7.0 \%$ ) of participants with normoglycemia and $8.8 \%$ (95\% Cl, $7.4 \%$ to $10.5 \%$ ) of those with prediabetes. The weighted prevalence of any retinopathy was $5.4 \%(95 \% \mathrm{Cl}, 4.4 \%$ to $6.5 \%)$ and $8.5 \%(95 \% \mathrm{Cl}, 7.2 \%$ to $10.2 \%)$ for those without and with hypertension respectively. Figure 1 shows the weighted prevalence of retinopathy stratified by glycemia and hypertension status among persons without diabetes. The weighted prevalence of retinopathy in normotensive and normoglycemia group was approximately $5.4 \%$ (95\% Cl, $4.2 \%$ to $6.9 \%)$ and increased to $12.5 \%$ (95\% Cl, 9.7\% to $16.0 \%$ ) in the hypertensive and prediabetes group ( $P_{\text {trend }}<0.001$ ). Figure 2 illustrates the relationship between level of HbAlc (a) SBP (b) and retinopathy in participants without diabetes. The weighted prevalence of retinopathy for those with a $\mathrm{HbAlc} \leq 4.5 \%$ was $5.4 \%(95 \% \mathrm{Cl}, 2.0 \%$ to $13.3 \%)$ and 
increased linearly $\left(P_{\text {trend }}=0.007\right)$. Similarly, the prevalence of retinopathy at SBP $<$ $100 \mathrm{mmHg}$ was $2.7 \%$ (95\% Cl, $1.1 \%$ to $6.4 \%$ ) and increased gradually with increasing levels of SBP ( $P$ trend $<0.001)$.

Table 2 provides the age and gender adjusted logistic regression models. Retinopathy signs were associated with ethnicity, education level, hypertension, SBP, DBP, HbAlc, CKD and history of stroke. After adjusting for multiple covariates selected from age and gender adjusted models, male gender ( $\mathrm{OR}, 1.54 ; 95 \% \mathrm{Cl}, 1.22$ to 1.93 ), systolic blood pressure (OR per $10 \mathrm{mmHg}$ increase, 1.11; $95 \% \mathrm{Cl}, 1.03$ to 1.19), HbAlc (OR per \% increase, 1.43; 95\% Cl, 1.01 to 2.05), and history of stroke (OR, 2.39; $95 \% \mathrm{Cl}, 1.14$ to 5.04 ) were independently associated with retinopathy (Table 3). When data was stratified by hypertension or glycemia status the results remained consistent and showed male gender, BP and history of stroke were associated with retinopathy (Supplement Table 2).

\section{DISCUSSION}

The results of this study showed that $6.7 \%$ of people aged 40 years and older in the U.S without diabetes showed signs of retinopathy with the majority having minimal-to-mild non-proliferative retinopathy. Male gender, SBP, HbAlc and history of stroke were independently associated with risk of retinopathy.

The frequent presence of retinopathy among those without diabetes in the U.S. population (6.7\%) is consistent with prevalence reported by the Singapore Indian Eye Study (5.05\%), ${ }^{12}$ Singapore Malay Eye Study (6\%), ${ }^{13}$ and Los Angeles Latino Eye Study (6.6\%). ${ }^{5}$ In contrast, it was lower than some studies which have reported the prevalence of retinopathy to range between $7.3 \%$ and $14.8 \%$. ${ }^{4,8-11,14,15,20-22}$ The difference in prevalence may arise from differences in population characteristics, study 
period, diagnosis of clinical diabetes, method of capturing fundus photography and grading methods. Supplement Table 3 summarizes the prevalence of retinopathy in persons without diabetes from different studies.

In our study, higher HbAlc was significantly associated with retinopathy lesions, even when adjustments were made for covariates. Moreover, a positive relationship between higher $\mathrm{HbAlc}$ and retinopathy signs was observed. This finding was supported by previous studies, ${ }^{11-14,23-25}$ suggesting that microvascular damage in the retina was associated with impaired glucose metabolism. We also supported the previous evidence of a strong association between retinopathy and blood pressure $e^{8,11,15,26,27}$ and this significant association still persisted in participants with normoglycemia or with prediabetes. Similar to $\mathrm{HbAlc}$, we also showed that prevalence of retinopathy increased in a positive linear pattern as SBP increased. These findings indicate that retinopathy signs might be associated with blood pressure dysfunction. However, in our study, retinopathy prevalence was as high as 5.4\% in non-diabetic persons with normal blood pressure. These findings suggest that only a proportion of non-diabetic patients with retinopathy could be explained by blood pressure and glucose metabolism. Furthermore, we highlighted the contribution history of stroke has on the presence of retinopathy in non-diabetic persons. This observation was in line with other studies, ${ }^{2,8,13,22}$ indicating that retinopathy signs may signal adverse cardiovascular risk profile.

Our study also found that the prevalence of retinopathy in non-diabetic participants was significantly higher in men, which was consistent with previous reports from Los Angeles Latino Eye Study, Handan Eye Study, and Tromsø Eye Study. ${ }^{5,11,14}$ On the contrary to the several studies, we did not find significant associations between retinopathy and obesity, ${ }^{5,9,10,13,15}$ hyperlipidemia, ${ }^{15}$ serum creatinine ${ }^{12}$ and inflammatory markers. ${ }^{28}$ Summary of the risk profile found in the 
previous studies have also shown in Supplement Table 3.

Although $98.2 \%$ of retinopathy in participants without diabetes was minimal-to-mild non-proliferative retinopathy, which may be transient and not sight-threatening, ${ }^{29,30}$ the frequency of retinopathy among participants without diabetes might challenge the current criteria for diabetes and hypertension. Recent studies documented that retinopathy signs may predict subsequent risk of clinical diabetes and hypertension. ${ }^{31,32}$ The Atherosclerosis Risk In Communities study indicated that retinopathy among non-diabetic participants with a family history of diabetes was an independent predictor of subsequent risk of clinical diabetes. ${ }^{31}$ Similarly, retinopathy signs were significantly associated with the incidence of hypertension and, in persons younger than 65 years, with the incidence of diabetes mellitus in the Beaver Dam Eye Study. ${ }^{32}$ Findings from this study have found an association between retinopathy and cardiovascular risk factors. In addition, this association of cardiovascular events and mortality ${ }^{33-38}$ has been found in previous studies which may have important clinical implications. For example, the presence of retinopathy signs may be a key indicator of microvascular dysfunction. ${ }^{39-42}$ Further investigations on the clinical implication and pathophysiology of retinopathy among non-diabetic participants are warranted.

The strength of this study is the inclusion of a large population-based national sample, comprehensive assessment of risk profiles, a large proportion of gradable fundus images, diagnosis of retinopathy status for both eyes and use of standardized photographic grading protocols. There are several potential limitations which warrant consideration. Firstly, the health effect may be a concern in the current analysis. Supplement Table 1 suggested a healthy participant effect that might lead to underestimation of the retinopathy prevalence. Secondly, due to the cross-sectional design in our study, we could not evaluate the direction of causality. Furthermore, the 
significant associations between retinopathy and risk factors need confirmation from further longitudinal studies.

In conclusion, $6.7 \%$ of the U.S. population without diabetes have retinopathy, mostly minimal-to-mild in severity. Male gender, SBP, HbAlc and history of stroke increased the odds for retinopathy signs in non-diabetic participants. Given the potential underlying adverse vascular risk profile of retinopathy, further studies are needed to clarify the natural history and underlying mechanisms of retinopathy among persons without diabetes.

\section{Abbreviations and Acronyms}

NHANES $=$ National Health and Nutrition Examination Survey; ETDRS $=$ Early Treatment Diabetic Retinopathy Study; SBP = systolic blood pressure; $\mathbf{D B P}=$ diastolic blood pressure; $\mathbf{H D L}=$ high-density lipoprotein; $\mathbf{H b A l c}=$ glycoslated hemoglobin levels; $\mathbf{B M I}=$ body mass index, $\mathbf{C R P}=$ C-reactive protein; $\mathbf{P I} \mathbf{R}=$ poverty income ratio; $\mathbf{C K D}=$ chronic kidney disease; $\mathbf{e G F R}=$ estimated glomerular filtration rate; $\mathbf{A C R}=$ albumin-creatinine ratio; $\mathbf{M E C}=$ mobile examination center; $\mathbf{S E}=$ standard errors; I QR = interquartile range; $\mathbf{O R}=$ odds ratios; $\mathbf{C I}=$ confidence interval. 


\section{REFERENCES}

1. Wong TY, Klein R, Sharrett AR, Manolio TA, Hubbard LD, Marino EK, Kuller L, Burke G, Tracy RP, Polak JF, Gottdiener JS, Siscovick DS. The prevalence and risk factors of retinal microvascular abnormalities in older persons: The Cardiovascular Health Study. Ophthalmology 2003; 110: 658-66.

2. Wong TY, Barr EL, Tapp RJ, Harper CA, Taylor HR, Zimmet PZ, Shaw JE. Retinopathy in persons with impaired glucose metabolism: the Australian Diabetes Obesity and Lifestyle (AusDiab) study. Am J Ophthalmo/ 2005; 140: 1157-9.

3. Zhang X, Saaddine JB, Chou CF, Cotch MF, Cheng YJ, Geiss LS, Gregg EW, Albright AL, Klein BE, Klein R. Prevalence of diabetic retinopathy in the United States, 2005-2008. JAMA 2010; 304: 649-56.

4. Gunnlaugsdottir E, Halldorsdottir S, Klein R, Eiriksdottir G, Klein BE, Benediktsson R, Harris TB, Launer LJ, Aspelund T, Gudnason V, Cotch MF, Jonasson F. Retinopathy in old persons with and without diabetes mellitus: the Age, Gene/Environment Susceptibility--Reykjavik Study (AGES-R). Diabetologia 2012; 55: 671-80.

5. Chao JR, Lai MY, Azen SP, Klein R, Varma R, Los Angeles Latino Eye Study G. Retinopathy in persons without diabetes: the Los Angeles Latino Eye Study. Invest Ophthalmol Vis Sci 2007; 48: 4019-25.

6. Wong TY, Islam FM, Klein R, Klein BE, Cotch MF, Castro C, Sharrett AR, Shahar E. Retinal vascular caliber, cardiovascular risk factors, and inflammation: the multi-ethnic study of atherosclerosis (MESA). Invest Ophthalmol Vis Sci 2006; 47: 2341-50.

7. Hirai FE, Moss SE, Knudtson MD, Klein BE, Klein R. Retinopathy and survival in a 
population without diabetes: The Beaver Dam Eye Study. AmJ Epidemio/2007; 166: $724-30$.

8. Wong TY, Hubbard LD, Klein R, Marino EK, Kronmal R, Sharrett AR, Siscovick DS, Burke G, Tielsch JM. Retinal microvascular abnormalities and blood pressure in older people: the Cardiovascular Health Study. Br J Ophthalmol 2002; 86: 1007-13.

9. Munch IC, Kessel L, Borch-J ohnsen K, Glumer C, Lund-Andersen H, Larsen M. Microvascular retinopathy in subjects without diabetes: the Inter99 Eye Study. Acta Ophthalmo/2012; 90: 613-9.

10. Kawasaki R, Wang JJ, Wong TY, Kayama T, Yamashita H. Impaired glucose tolerance, but not impaired fasting glucose, is associated with retinopathy in Japanese population: the Funagata study. Diabetes Obes Metab 2008; 10: 514-5.

11. Bertelsen G, Peto T, Lindekleiv $H$, Schirmer H, Solbu MD, Toft I, Sjolie AK, Njolstad I. Sex differences in risk factors for retinopathy in non-diabetic men and women: the Tromso Eye Study. Acta Ophthalmo/ 2014; 92: 316-22.

12. Bhargava M, Cheung CY, Sabanayagam C, Huang L, Lamoureux EL, Wang JJ, Tai ES, Heng CK, I kram MK, Mitchell P, Wong TY. Prevalence and risk factors for retinopathy in persons without diabetes: the Singapore Indian Eye Study. Acta Ophthalmo/2014; 92: e602-9.

13. Jeganathan VS, Cheung N, Tay WT, Wang JJ, Mitchell P, Wong TY. Prevalence and risk factors of retinopathy in an Asian population without diabetes: the Singapore Malay Eye Study. Arch Ophthalmo/2010; 128: 40-5.

14. Peng XY, Wang FH, Liang YB, Wang J J, Sun LP, Peng Y, Friedman DS, Liew G, Wang NL, Wong TY. Retinopathy in persons without diabetes: the Handan Eye Study. Ophthalmology 2010; 117: 531-7, 7 e1-2. 
15. van Leiden HA, Dekker J M, Moll AC, Nijpels G, Heine RJ, Bouter LM, Stehouwer $\mathrm{CD}$, Polak BC. Blood pressure, lipids, and obesity are associated with retinopathy: the hoorn study. Diabetes Care 2002; 25: 1320-5.

16. Centers for Disease Control and Prevention, National Center for Health Statistics. National Health and Nutrition Examination Survey Data. Hyattsville, MD: US Department of Health and Human Services, Centers for Disease Control and Prevention; 2005. Available at: http://www.cdc.gov/nchs/nhanes.htm. Accessed February 11, 2018.

17. Klein R, Meuer SM, Moss SE, Klein BE, Neider MW, Reinke J. Detection of age-related macular degeneration using a nonmydriatic digital camera and a standard film fundus camera. Arch Ophthalmo/2004; 122: 1642-6.

18. Klein R, Klein BE, Magli YL, Brothers RJ, Meuer SM, Moss SE, Davis MD. An alternative method of grading diabetic retinopathy. Ophthalmology 1986; 93: 1183-7.

19. Carlson SA, Fulton JE, Schoenborn CA, Loustalot F. Trend and prevalence estimates based on the 2008 Physical Activity Guidelines for Americans. Am J Prev Med 2010; 39: 305-13.

20. Klein R, Klein BE, Moss SE, Wang Q. Hypertension and retinopathy, arteriolar narrowing, and arteriovenous nicking in a population. Arch Ophthalmo/ 1994; 112: $92-8$.

21. Yu T, Mitchell P, Berry G, Li W, Wang JJ. Retinopathy in older persons without diabetes and its relationship to hypertension. Arch Ophthalmol 1998; 116: 83-9.

22. Ojaimi E, Nguyen TT, Klein R, Islam FM, Cotch MF, Klein BE, Wang JJ, Wong TY. Retinopathy signs in people without diabetes: the multi-ethnic study of atherosclerosis. Ophthalmology 2011; 118: 656-62. 
23. Gabir MM, Hanson RL, Dabelea D, Imperatore G, Roumain J, Bennett PH, Knowler WC. Plasma glucose and prediction of microvascular disease and mortality: evaluation of 1997 American Diabetes Association and 1999 World Health Organization criteria for diagnosis of diabetes. Diabetes Care 2000; 23: $1113-8$.

24. Nguyen TT, Wang JJ, Islam FM, Mitchell P, Tapp RJ, Zimmet PZ, Simpson R, Shaw J, Wong TY. Retinal arteriolar narrowing predicts incidence of diabetes: the Australian Diabetes, Obesity and Lifestyle (AusDiab) Study. Diabetes 2008; 57: 536-9.

25. Nguyen TT, Wang JJ, Wong TY. Retinal vascular changes in pre-diabetes and prehypertension: new findings and their research and clinical implications. Diabetes Care 2007; 30: 2708-15.

26. Klein $\mathrm{R}$, Myers $\mathrm{CE}$, Lee $\mathrm{KE}$, Klein BE. 15-year cumulative incidence and associated risk factors for retinopathy in nondiabetic persons. Arch Ophthalmol 2010; 128: 1568-75.

27. Wong TY, Mitchell P. The eye in hypertension. Lancet 2007; 369: 425-35.

28. van Hecke MV, Dekker J M, Nijpels G, Moll AC, Heine RJ, Bouter LM, Polak BC, Stehouwer CD. Inflammation and endothelial dysfunction are associated with retinopathy: the Hoorn Study. Diabetologia 2005; 48: 1300-6.

29. Cugati S, Cikamatana L, Wang JJ, Kifley A, Liew G, Mitchell P. Five-year incidence and progression of vascular retinopathy in persons without diabetes: the Blue Mountains Eye Study. Eye (Lond) 2006; 20: 1239-45.

30. Wong TY, Klein R, Amirul Islam FM, Cotch MF, Couper DJ, Klein BE, Hubbard LD, Sharrett AR. Three-year incidence and cumulative prevalence of retinopathy: the atherosclerosis risk in communities study. Am J Ophthalmo/ 2007; 143: 970-6. 
31. Wong TY, Mohamed Q, Klein R, Couper DJ. Do retinopathy signs in non-diabetic individuals predict the subsequent risk of diabetes? Br J Ophtha/mo/ 2006; 90: 301-3.

32. Klein R, Klein BE, Moss SE, Wong TY. The relationship of retinopathy in persons without diabetes to the 15-year incidence of diabetes and hypertension: Beaver Dam Eye Study. Trans Am Ophthalmol Soc 2006; 104: 98-107.

33. Van Hecke MV, Dekker J M, Nijpels G, Moll AC, Van Leiden HA, Heine RJ, Bouter LM, Stehouwer CD, Polak BC, Hoorn S. Retinopathy is associated with cardiovascular and all-cause mortality in both diabetic and nondiabetic subjects: the hoorn study. Diabetes Care 2003; 26: 2958.

34. Xu L, Wang YX, Xie XW, Jonas JB. Retinopathy and mortality. The Beijing Eye Study. Graefes Arch Clin Exp Ophthalmo/2008; 246: 923-5.

35. Sairenchi T, Iso H, Yamagishi K, Irie F, Okubo Y, Gunji J, Muto T, Ota H. Mild retinopathy is a risk factor for cardiovascular mortality in Japanese with and without hypertension: the Ibaraki Prefectural Health Study. Circulation 2011; 124: 2502-11.

36. Juutilainen A, Lehto S, Ronnemaa T, Pyorala K, Laakso M. Retinopathy predicts cardiovascular mortality in type 2 diabetic men and women. Diabetes Care 2007; 30: $292-9$.

37. Fuller JH, Stevens LK, Wang SL. Risk factors for cardiovascular mortality and morbidity: the WHO Mutinational Study of Vascular Disease in Diabetes. Diabetologia 2001; 44 Suppl 2: S54-64.

38. Cusick M, Meleth AD, Agron E, Fisher MR, Reed GF, Knatterud GL, Barton FB, Davis MD, Ferris FL, 3rd, Chew EY, Early Treatment Diabetc Retinopathy Study Research G. Associations of mortality and diabetes complications in patients with type 1 and type 2 diabetes: early treatment diabetic retinopathy study 
report no. 27. Diabetes Care 2005; 28: 617-25.

39. Wong TY, Mclntosh R. Hypertensive retinopathy signs as risk indicators of cardiovascular morbidity and mortality. Br Med Bull 2005; 73-74: 57-70.

40. Crosby-Nwaobi RR, Sivaprasad S, Amiel S, Forbes A. The relationship between diabetic retinopathy and cognitive impairment. Diabetes Care 2013; 36: 3177-86.

41. Grunwald JE, Pistilli M, Ying GS, Daniel E, Maguire MG, Xie D, Whittock-Martin R, Parker Ostroff C, Lo JC, Townsend RR, Gadegbeku CA, Lash JP, Fink JC, Rahman M, Feldman HI, Kusek JW, Chronic Renal Insufficiency Cohort Study I. Retinopathy and progression of CKD: The CRIC study. Clin J Am Soc Nephrol 2014; 9: 1217-24.

42. Grunwald JE, Alexander J, Ying GS, Maguire M, Daniel E, Whittock-Martin R, Parker C, McWilliams K, Lo J C, Go A, Townsend R, Gadegbeku CA, Lash JP, Fink JC, Rahman M, Feldman H, Kusek JW, Xie D, Jaar BG, Group CS. Retinopathy and chronic kidney disease in the Chronic Renal Insufficiency Cohort (CRIC) study. Arch Ophthalmol 2012; 130: 1136-44.

\section{FIGURES}




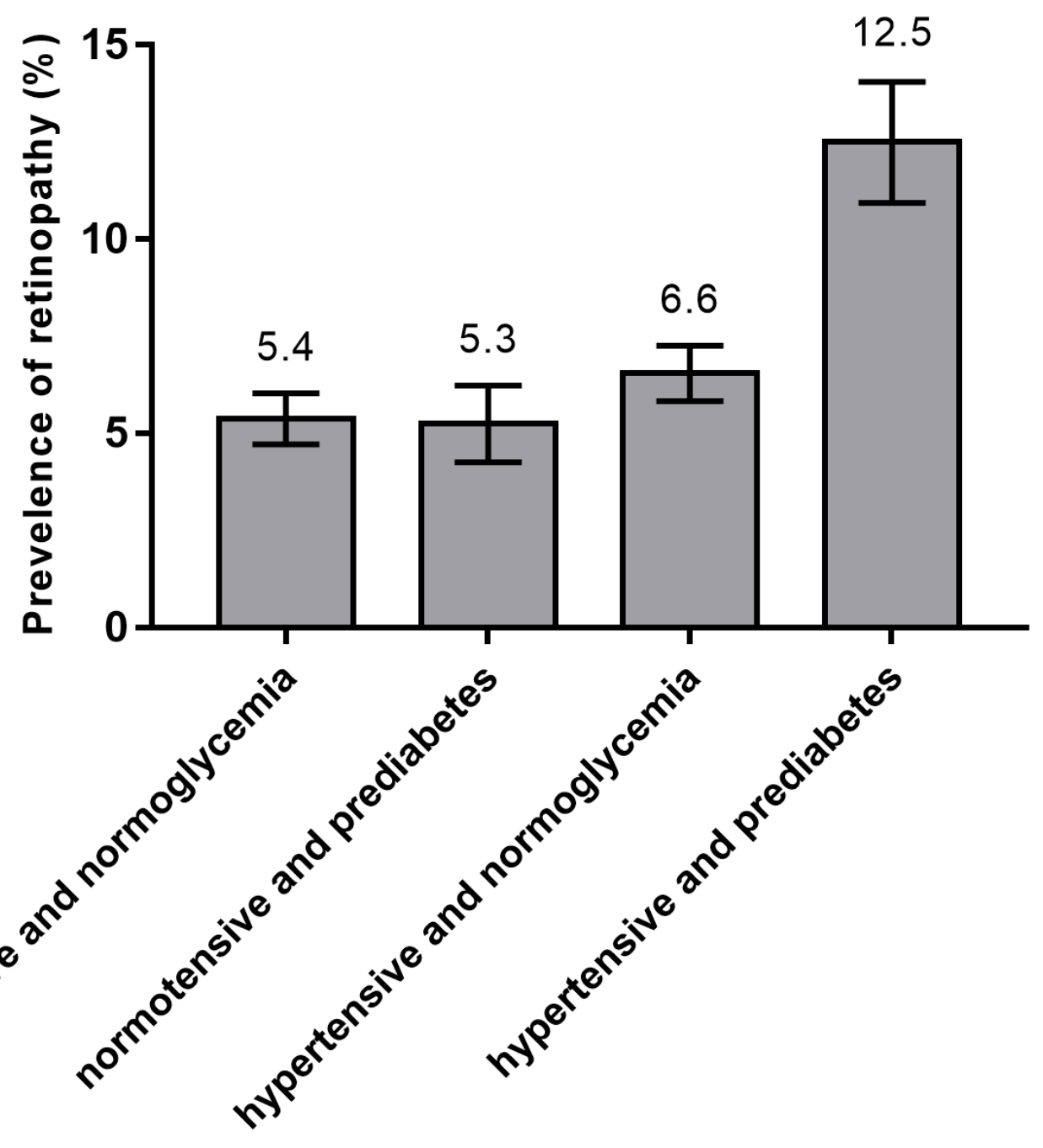

Figure 1: The weighted prevalence of retinopathy stratified by glycemia and hypertension status among persons without diabetes. The weighted prevalence of retinopathy in normotensive and normoglycemia group was approximately 5.4\% (95\% $\mathrm{Cl}, 4.2 \%$ to $6.9 \%)$ and increased to $12.5 \%(95 \% \mathrm{Cl}, 9.7 \%$ to $16.0 \%)$ in hypertensive and prediabetes group $\left(P_{\text {trend }}<0.001\right)$. Error bars represent \pm 1 SEM. 


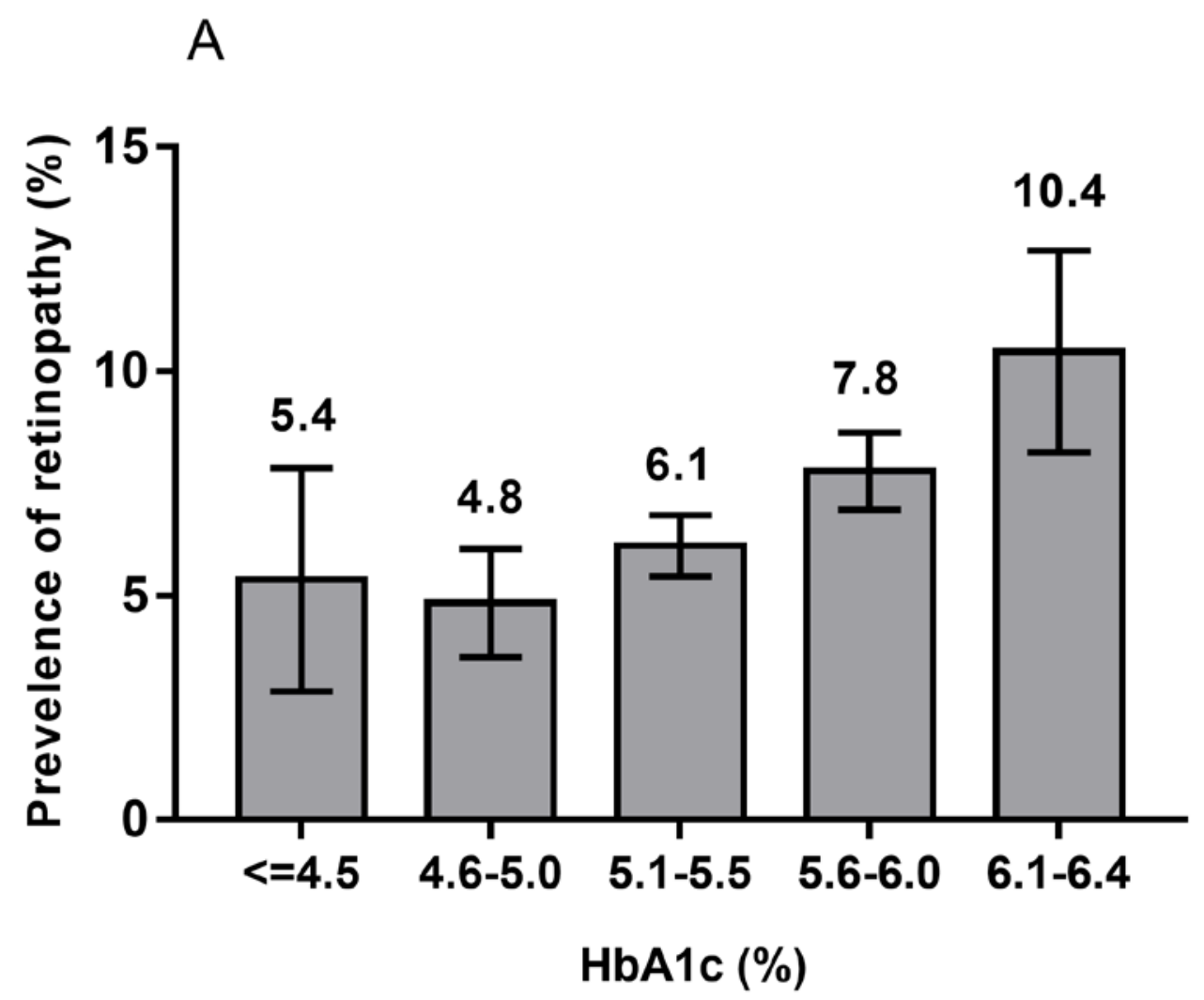

B

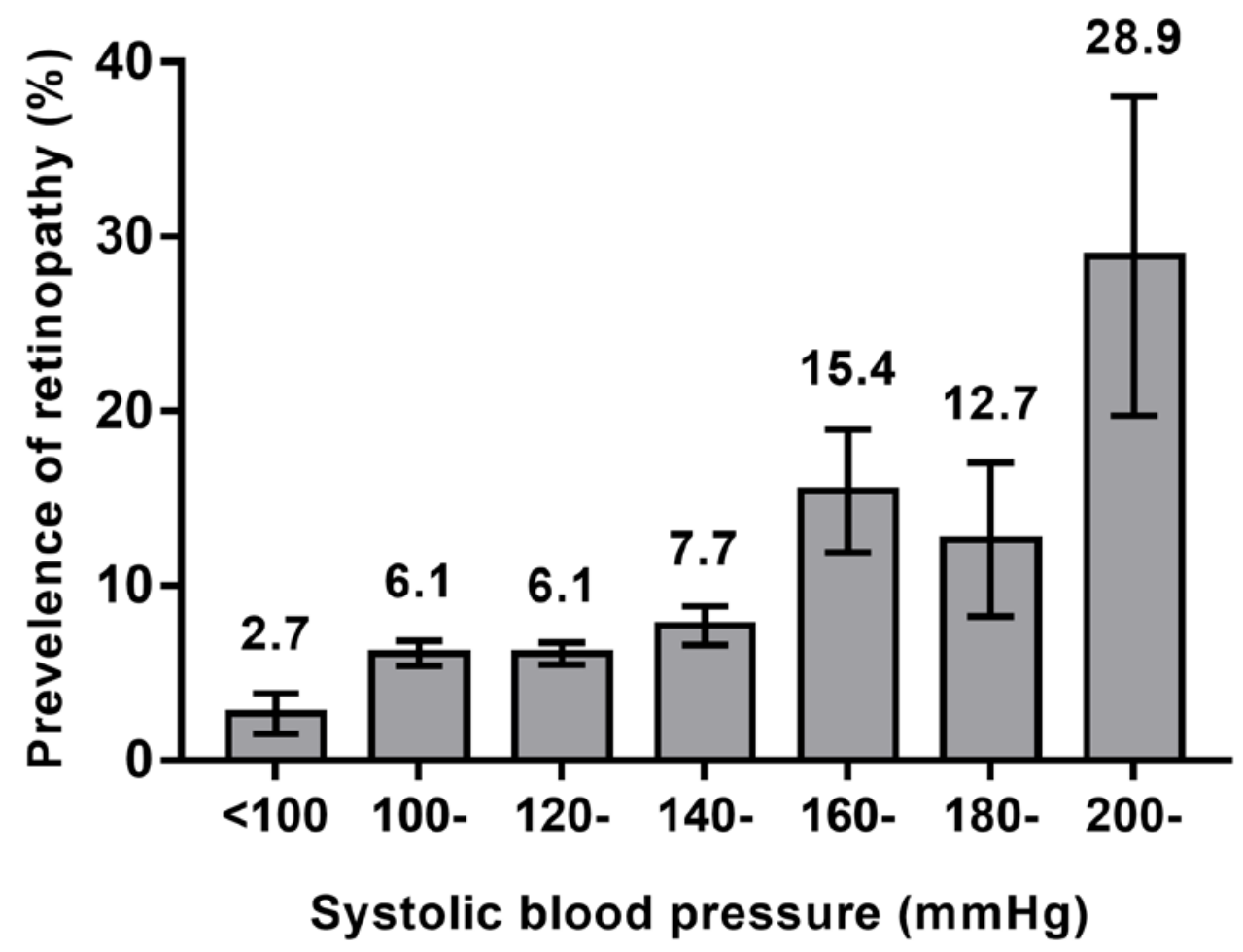


Figure 2: Relation between level of $\operatorname{HbAlc}(A)$ or SBP (B) and retinopathy in participants without diabetes. The weighted prevalence of retinopathy at $\mathrm{HbAlc} \leq 4.5 \%$ is $5.4 \%(95 \% \mathrm{Cl}, 2.0 \%$ to $13.3 \%)$ and increases in a linear pattern $(P$ trend $=0.007)$. The prevalence of retinopathy at SBP $<100 \mathrm{mmHg}$ is $2.7 \%(95 \% \mathrm{Cl}, 1.1 \%$ to $6.4 \%)$ and increases gradually with increasing levels of SBP $(P$ trend $<0.001)$. Error bars represent \pm 1 SEM. 


\section{TABLES}

Table 1: Demographic, Health-Related Behaviors and General Health Characteristics of Non-Diabetic Participants With and Without Retinopathy ${ }^{a}$

\begin{tabular}{|c|c|c|c|c|}
\hline Characteristics & $\begin{array}{l}\text { Overall, } \\
N=4,354\end{array}$ & $\begin{array}{c}\text { No } \\
\text { Retinopathy, } \\
n=4,013(\%)\end{array}$ & $\begin{array}{c}\text { Any } \\
\text { Retinopathy, } \\
\mathrm{n}=\mathbf{3 4 1}(\%)\end{array}$ & $\begin{array}{c}\text { Unadjuste } \\
\text { d } \\
\text { P Value }^{\mathrm{b}} \\
\end{array}$ \\
\hline Age mean $\pm S E$, yrs & $55.6 \pm 0.39$ & $55.4 \pm 0.38$ & $58.7 \pm 1.16$ & 0.004 \\
\hline Male sex & $2,163(47.0)$ & $1,969(46.4)$ & $194(55.8)$ & 0.003 \\
\hline \multicolumn{5}{|l|}{ Race } \\
\hline Non-Hispanic white & $2,517(79.6)$ & $2,343(80.0)$ & $174(74.0)$ & 0.23 \\
\hline Non-Hispanic black & $761(7.9)$ & $685(7.8)$ & $76(9.9)$ & \\
\hline Mexican American & $639(5.0)$ & $586(4.9)$ & $53(5.9)$ & \\
\hline Other & $437(7.5)$ & $399(7.3)$ & $38(10.2)$ & \\
\hline High school and over education & $3,206(83.7)$ & $2,977(84.1)$ & $229(79.3)$ & 0.01 \\
\hline Married/with a partner & $2,806(69.8)$ & $2,584(69.7)$ & $222(70.9)$ & 0.65 \\
\hline Income at or above poverty & $3,488(91.5)$ & $3,206(91.4)$ & $282(93.1)$ & 0.36 \\
\hline Former/current smoker & $2,273(51.1)$ & $2,085(50.7)$ & $188(56.4)$ & 0.10 \\
\hline \multicolumn{5}{|l|}{ Alcohol consumption } \\
\hline Abstainer/former drinker & $958(18.4)$ & $870(17.8)$ & $88(26.3)$ & 0.01 \\
\hline $\begin{array}{cc}\text { Current } & \text { drinker } \\
\text { drinks/week) }\end{array}$ & $2,326(55.8)$ & $2,161(56.5)$ & $165(45.9)$ & \\
\hline $\begin{array}{cc}\text { Current } & \text { drinker } \\
\text { drinks/week) }\end{array}$ & $987(25.8)$ & $905(25.7)$ & $82(27.9)$ & \\
\hline Meet PA recommendation & $2,279(70.2)$ & $2,117(70.2)$ & $162(69.7)$ & 0.91 \\
\hline \multicolumn{5}{|l|}{ Blood pressure } \\
\hline Hypertension & $1,908(39.2)$ & $1,708(38.4)$ & $200(50.8)$ & 0.002 \\
\hline Systolic mean $\pm \mathrm{SE}, \mathrm{mmHg}$ & $125.2 \pm 0.45$ & $124.8 \pm 0.46$ & $130.3 \pm 1.29$ & $<0.001$ \\
\hline Diastolic mean $\pm \mathrm{SE}, \mathrm{mmHg}$ & $72.9 \pm 0.28$ & $72.8 \pm 0.28$ & $73.5 \pm 0.77$ & 0.40 \\
\hline \multicolumn{5}{|l|}{ Serum lipids } \\
\hline Hyperlipidemia & $1,537(35.2)$ & $1,415(35.1)$ & $122(35.7)$ & 0.83 \\
\hline $\begin{array}{l}\text { Total cholesterol mean } \pm S E \text {, } \\
\mathrm{mg} / \mathrm{dL}\end{array}$ & $206.4 \pm 0.80$ & $206.7 \pm 0.81$ & $201.1 \pm 3.54$ & 0.13 \\
\hline $\mathrm{HDL}$ mean $\pm \mathrm{SE}, \mathrm{mg} / \mathrm{dL}$ & $55.0 \pm 0.39$ & $55.0 \pm 0.40$ & $54.1 \pm 0.97$ & 0.38 \\
\hline HbAlc median (IQR), \% & $5.4(5.2-5.7)$ & $5.4(5.2-5.7)$ & $5.5(5.2-5.7)$ & 0.003 \\
\hline
\end{tabular}




\begin{tabular}{lcccc}
\hline $\begin{array}{l}\text { Nonfasting glucose median (IQR), } \\
\text { mg/dL }\end{array}$ & $93(86-101)$ & $92(86-101)$ & $93(86-103)$ & 0.38 \\
$\begin{array}{l}\text { Body Mass Index mean } \pm \mathrm{SE}, \mathrm{kg} / \mathrm{m}^{2} \\
\text { Waist circumference mean } \pm \mathrm{SE}, \mathrm{cm}\end{array}$ & $28.5 \pm 0.14$ & $28.5 \pm 0.15$ & $28.4 \pm 0.35$ & 0.79 \\
$\begin{array}{l}\text { High CRP } \\
\text { Self-reported }\end{array}$ & $436(9.3)$ & $401(9.4)$ & $35(7.7)$ & 0.28 \\
$\quad$ Congestive heart failure & $127(2.1)$ & $114(2.1)$ & $13(2.9)$ & 0.35 \\
$\quad$ coronary heart disease & $194(3.7)$ & $168(3.5)$ & $26(6.2)$ & 0.09 \\
$\quad \begin{array}{l}\text { angina } \\
\text { heart attack }\end{array}$ & $134(2.6)$ & $118(2.5)$ & $16(4.0)$ & 0.15 \\
$\quad$ stroke & $203(3.6)$ & $180(3.5)$ & $23(4.7)$ & 0.36 \\
Renal function & $165(2.9)$ & $135(2.6)$ & $30(7.4)$ & $\mathbf{0 . 0 2}$ \\
$\quad$ Serum creatinine median (IQR), & $0.9(0.8-1.02)$ & $0.9(0.8-1.01)$ & $0.9(0.8-1.07)$ & $\mathbf{0 . 0 0 1}$ \\
mg/dL & $863(15.6)$ & $766(15.1)$ & $97(23.3)$ & $\mathbf{0 . 0 0 6}$ \\
$\quad$ CKD & & &
\end{tabular}

Abbreviations: SE, standard error; IQR, interquartile range; PA, physical activity; HDL, high-density lipoprotein cholesterol; CRP, C-reactive protein; CKD, chronic kidney disease. Boldface indicates statistical significance $(P<0.05)$.

a All proportions are weighted estimates of the US population characteristics, taking into account the complex sampling design of the National Health and Nutrition Examination Survey.

b All $P$ values were calculated using t-test for continuous variables and the design-adjusted Rao-Scott Pearson $\mathrm{x}^{2}$ test for categorical variables. 


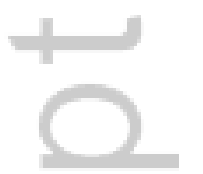

4 
Table 2: Age- and Gender-Adjusted Logistic Regression Models for Non-Diabetic Participants $^{a}$

\begin{tabular}{|c|c|c|}
\hline Characteristics & $\begin{array}{c}\text { Age- and } \\
\text { Gender-Adjusted } \\
\text { OR }(95 \% \mathrm{Cl}) \\
\end{array}$ & $\begin{array}{c}\mathbf{P} \\
\text { Value }\end{array}$ \\
\hline Age, per 1 yrs increase & $1.02(1.01-1.04)$ & 0.002 \\
\hline Male vs female & $1.50(1.18-1.90)$ & 0.002 \\
\hline \multicolumn{3}{|l|}{ Race } \\
\hline Non-Hispanic white & 1.00 & 0.01 \\
\hline Non-Hispanic black & $1.52(1.02-2.27)$ & \\
\hline Mexican American & $1.48(1.00-2.21)$ & \\
\hline Other & $1.69(0.97-2.92)$ & \\
\hline $\begin{array}{l}\text { High school and over education vs } \\
\text { less }\end{array}$ & $0.79(0.61-1.01)$ & 0.06 \\
\hline $\begin{array}{l}\text { Married/with a partner vs unmarried } \\
\text { or other }\end{array}$ & $1.07(0.81-1.42)$ & 0.61 \\
\hline $\begin{array}{l}\text { Income at or above poverty vs below } \\
\text { poverty }\end{array}$ & $1.21(0.68-2.14)$ & 0.51 \\
\hline $\begin{array}{l}\text { Former/current smoker vs } \\
\text { non-smoker }\end{array}$ & $1.16(0.86-1.56)$ & 0.32 \\
\hline \multicolumn{3}{|l|}{ Alcohol consumption } \\
\hline Abstainer/former drinker & 1.00 & 0.30 \\
\hline Current drinker ( $\leq 3$ drinks/week) & $0.56(0.41-0.79)$ & \\
\hline Current drinker (>3 drinks/week) & $0.71(0.42-1.20)$ & \\
\hline $\begin{array}{l}\text { Meet PA recommendation vs not } \\
\text { meet }\end{array}$ & $0.96(0.60-1.55)$ & 0.88 \\
\hline \multicolumn{3}{|l|}{ Blood pressure } \\
\hline Hypertension vs normotension & $1.46(1.07-1.99)$ & 0.02 \\
\hline Systolic, per $10 \mathrm{mmHg}$ increase & $1.13(1.06-1.21)$ & 0.001 \\
\hline Diastolic, per $10 \mathrm{mmHg}$ increase & $1.11(0.99-1.25)$ & 0.08 \\
\hline \multicolumn{3}{|l|}{ Serum lipids } \\
\hline Hyperlipidemia vs normolipidemia & $0.92(0.72-1.18)$ & 0.50 \\
\hline $\begin{array}{l}\text { Total cholesterol, per } 1 \mathrm{mg} / \mathrm{dL} \\
\text { increase }\end{array}$ & $1.00(0.99-1.00)$ & 0.27 \\
\hline $\mathrm{HDL}$, per $1 \mathrm{mg} / \mathrm{dL}$ increase & $1.00(0.99-1.01)$ & 0.92 \\
\hline $\mathrm{HbAlc}$, per $1 \%$ increase & $1.50(1.04-2.16)$ & 0.03 \\
\hline
\end{tabular}




\begin{tabular}{|c|c|c|}
\hline $\begin{array}{l}\text { Nonfasting glucose, per } 1 \mathrm{mg} / \mathrm{dL} \\
\text { increase }\end{array}$ & $1.00(0.99-1.01)$ & 0.74 \\
\hline $\begin{array}{l}\text { Body Mass Index, per } 1 \mathrm{~kg} / \mathrm{m}^{2} \\
\text { increase }\end{array}$ & $1.00(0.98-1.02)$ & 0.99 \\
\hline $\begin{array}{l}\text { Waist circumference, per } 1 \mathrm{~cm} \\
\text { increase }\end{array}$ & $1.00(0.99-1.01)$ & 0.97 \\
\hline High CRP vs normal CRP & $0.84(0.55-1.31)$ & 0.44 \\
\hline \multicolumn{3}{|l|}{ Self-reported } \\
\hline Congestive heart failure vs absent & $1.05(0.56-1.94)$ & 0.88 \\
\hline coronary heart disease vs absent & $1.26(0.74-2.15)$ & 0.38 \\
\hline angina vs absent & $1.26(0.69-2.31)$ & 0.44 \\
\hline heart attack vs absent & $0.98(0.60-1.59)$ & 0.93 \\
\hline stroke vs absent & $2.50(1.30-4.81)$ & 0.007 \\
\hline \multicolumn{3}{|l|}{ Renal function } \\
\hline $\begin{array}{l}\text { Serum creatinine, per } 1 \mathrm{mg} / \mathrm{dL} \\
\text { increase }\end{array}$ & $1.15(0.89-1.49)$ & 0.28 \\
\hline CKD vs absent & $1.43(1.04-1.97)$ & 0.03 \\
\hline
\end{tabular}

Abbreviations: OR, odds ratio; PA, physical activity; $\mathrm{HDL}$, high-density lipoprotein cholesterol; CRP, C-reactive protein; CKD, chronic kidney disease. Boldface indicates statistical significance $(P<0.1)$.

a All proportions are weighted estimates of the US population characteristics, taking into account the complex sampling design of the National Health and Nutrition Examination Survey. 
Table 3: Multiple Adjusted Logistic Regression Models for Non-Diabetic Participants ${ }^{a}$

\begin{tabular}{lcc}
\hline \multicolumn{1}{c}{ Characteristics } & $\begin{array}{c}\text { Multiple Adjusted } \\
\text { OR (95\% Cl) }\end{array}$ & $\begin{array}{c}\text { P } \\
\text { Value }\end{array}$ \\
\hline Age, per 1 yrs increase & $1.01(0.99-1.02)$ & 0.43 \\
Male vs female & $1.54(1.22-1.93)$ & $\mathbf{0 . 0 0 1}$ \\
Race & & \\
$\quad$ Non-Hispanic white & 1.00 & \\
Non-Hispanic black & $1.24(0.87-1.77)$ & 0.23 \\
Mexican American & $1.33(0.86-2.03)$ & 0.19 \\
Other & $1.54(0.87-2.74)$ & 0.13 \\
High school and over education vs & $0.91(0.68-1.21)$ & 0.49 \\
less & & \\
Hypertension vs normotension & $1.13(0.78-1.64)$ & 0.49 \\
Systolic, per 10 mmHg increase & $1.11(1.03-1.19)$ & $\mathbf{0 . 0 0 6}$ \\
Diastolic, per 10 mmHg increase & $1.00(0.89-1.13)$ & 0.99 \\
HbAlc, per 1 \% increase & $1.43(1.01-2.05)$ & $\mathbf{0 . 0 5}$ \\
Self-reported stroke vs absent & $2.39(1.14-5.04)$ & $\mathbf{0 . 0 2}$ \\
CKD vs absent & $1.34(0.96-1.87)$ & 0.09 \\
\hline
\end{tabular}

Abbreviations: OR, odds ratio; CKD, chronic kidney disease. Boldface indicates statistical significance $(P<0.05)$.

a All proportions are weighted estimates of the US population characteristics, taking into account the complex sampling design of the National Health and Nutrition Examination Survey. 


\section{University Library}

\section{- M M N E R VA A gateway to Melbourne's research publications}

Minerva Access is the Institutional Repository of The University of Melbourne

Author/s:

Zhu, Z;Wang, W;Scheetz, J;Zhang, J;He, M

Title:

Prevalence and risk profile of retinopathy in non-diabetic subjects: National Health and Nutrition Examination Survey 2005 to 2008

Date:

2019-08-02

\section{Citation:}

Zhu, Z., Wang, W., Scheetz, J., Zhang, J. \& He, M. (2019). Prevalence and risk profile of retinopathy in non-diabetic subjects: National Health and Nutrition Examination Survey 2005 to 2008. CLINICAL AND EXPERIMENTAL OPHTHALMOLOGY, 47 (9), pp.1173-1181. https:// doi.org/10.1111/ceo.13595.

Persistent Link:

http://hdl.handle.net/11343/286240 